\title{
TITLE:
}

\section{Circular Polarization of Sunlight Reflected by Planetary Atmospheres(Abstract_要旨)}

$\operatorname{AUTHOR}(\mathrm{S})$ :

Kawata, Takeyuki

\section{CITATION:}

Kawata, Takeyuki. Circular Polarization of Sunlight Reflected by Planetary Atmospheres. 京都大学, 1977, 理学博士

ISSUE DATE:

1977-09-24

URL:

http://hdl.handle.net/2433/221565

RIGHT: 


\section{【92】}
氏
名

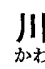
界髅
$\sum_{i=3}$
学位の種類
理
学
博
士
学位記 番号
論 理 博 第 580 号
学位授与の日付
昭 和 52 年 9 月 24 日
学位授与の要件
学位規則第 5 条第 2 項該当
学位論文題目

\section{Circular Polarization of Sunlight Reflected by} Planetary Atmospheres

(惑星大気によって反射された太陽光の円偏光)

論文調査委員 教主晏) 小暮智一 教授長谷川博一 教 授 加藤正二

\section{論交内容の要旨}

1971年に Kemp, Swedlund らは木星表面からの太陽反射光に円偏光成分の存在を検出したが，その 後，火星，金星，水星，土星などからも検出されている。てれらの円偏光成分は次のような共通の特徴 をもっている。第 1 亿, 惑星面の北半球之南半球とでは偏光の向きが逆である。第 2 亿, 同じ半球にお いても惑星が衝の位置を通過するときに偏光の向きが逆転する。第 3 に, 円偏光の偏光率は惑星によっ て多少異なるがいずれあ小さく，ストークスパラメーターにして V $/ \mathrm{I} \sim 10^{-3}-10^{-5}$ の程度である。この ような観测 特性を惑星大気中における多重散乱過程に求めようとする試みはすでに 1971 年に Kemp, Hansen らによってなされているが，1976年に申請者は Hansen と共に固体微粒子による多重散乱よ して木星反射光の円偏光特性を解明するととに成功した（参考諭文 5 )。

主論文は参考論文 5 の結果をさらに発展させ, 惑星大気中の固体微粒子小よび気体分子による散乱過 程の考察を精密化するとともに，その結果を木星，土星㧍よび金星の円偏光に応用したもので，惑星大 気に打ける光散乱理諭に大きく貢献するものである。

申請者はまず, 惑星大気は球状の固体微粒子からなり, 粒子の屈折率および有効サイズはパラメータ 一として与えられるものとして, 無偏光の平行入射光束に対する反射光のストークスパラメーターを理 論的に計算し, contour diagram として表現した。そのさい, 散乱過程としては単一散乱, 多重散乱, および多重散乱が Rayleigh 散乱と混在する場合と 3 通り老考えている。

第一に, 単一散乱についての contour diagram は直線偏光成分について, Rayleigh 散乱, Fresnel 散乱, 異常屈折㧍よび第一次虹散乱がパラメーターの連続的変化によってそれぞれ再現され，乙れらが 統一的に自然に理解されるという, 注目すべき結果を与えている。第二に, 円偏光成分は多重散乱によ ってはじめて発生し, 円偏光成分の contour diagram は円偏光の観測特性を近似的に雨現する。第三 に, Mie 散乱に対するRayleigh 散乱の影響を両者が均質に存在する場合と成層化して存在する場合に ついて検討した結果，いずれも Rayleigh 散乱の寄与が大きくなると反射光の円偏光率に大きな影響が 
あらわれる。以上の contour diagram に関する理論的計算の結果は惑星大気中における散乱過程の研 究に大きく寄与するものである。

つついて申請者は計算された contour diagram を木星，土星，および金星の表面反射光に応用を試 みている。一般に理論的円偏光は散乱粒子の屈折率と粒子のサイズによって特有の位相角および波長と の関係を示すから，てれを観測と比較するととにより，散乱粒子のパラメーターについて許容される範 囲を求めることができる。木星, 土星について申請者はこの許容範囲を推定したが，その範囲はかなり 幅の広いものとならざるをえなかった。その理由の一つは観测された光の波長域が限られていて, 波長 依存性を十分に比較できなかったためである。また, 土星の場合, 理論的円偏光率が観測值より 1 枌小 さい点について, 申請者は散乱粒子の非球対称性, または土星の輪からの反射光の奇与を示唆している。 金星については観测資料が一層不十分なので，申請者は円偏光の表面分布について理論的予测図を作製 し，今後の観测に対する興味深い間題提起を行っている。

以上要約する之, 本諭文は惑星大気中の多重散乱による円偏光の理諭的研究に主体があり, この面か ら, 惑星大気の今後の観測的研究に多くの示唆を与えるもの之なっている。

参考論文 $1 ， 2$ は輻射輸達方程式の基礎概念の検討㧍よび解法に関するものであり, 参考諭文 3,4 は土星の輪の表面輝度の位相変化に関する理論的研究である。参考諭文 5 はすでにのべたように木星円 偏光の理論的研究で主論文の基礎となったものである。参考論文 6 は輻射輸達理諭の応用として地表の 衛星写真に関するリモートセンシングを扱ったものである。

\section{論 交審 查の結果の要旨}

惑星大気に㧍ける光の散乱過程は惑星表面における太陽反射光から惑星大気の構造を探る上で基本的 な物理過程の一つであり, 従来は反射光強度および直線偏光の位相角依存性, とくに, 惑星の衝の前後 における強度変化などから種々の推論がなされてきた。1971年に発見された円偏光成分とその位相角之 の関係はこの問題に新しい観測資料を提供するるのである。

円偏光成分の起源が惑星大気中の多重散乱によるあのであるうという示唆はすでに1971年頃からなさ れているが，てれに対して広般な理論的研究を行ったのは1976年の申請者および Hansen によるすの が最初である(参考諭文 5 )。

主論文において, 申請者は1976年の仕事を発展させ, 一般の惑星大気内での固体微粒子および気体分 子による散乱過程を Contour Diagram 上に表現して詳細に愉討し，その結果を木星，上星，および金 星の円偏光に応用している。ここで Contour Diagram とは散乱粒子の屈折率をパラメーターとし, 散 乱の直線偏光または円偏光成分の, 微粒子有効サイズおよび散乱位相角に対する依存性を等強度曲線の 形で図に示したもので，パラメーター垈存性を視覚的に示す図である。

申請者の研究によって得られた新しい知見を要約すると次の 3 点をあげるととができる。

（1）球状の固体微粒子からなる惑星大気中での散乱過程を Contour Diagram の形で表現する方法を 提唱し，かつ，実際に広般な計算を害行して単一散乱，多重散乱の場合について Contour Diagramを 作成し応用への途を開いた。 
(2) 二粒子散乱の単純な散乱モデルについて散乱の位相マトリックスを厳密に計算し, 単一散乱では 直線偏光のみ生じて円偏光成分はあらわれず，2 回以上の多重散乱によって，はじめて円偏光成分の生 じることを解析的に示した。

（3）惑星大気への応用。計算された Contour Diagram を惑星反射光中に榆出された円偏光の観測特 性と比較するととにより惑星大気中の固体微粒子の屈折率, 有効サイズ, および Rayleigh 散乱の効果 などの推定を試みた。木星, 土星については衝の前後に拉ける円偏光の変化から上記パラメーターに対 する許容範囲を求めたが，その範盲はかなり広いものとならざるをえなかった。一つの理由は観測され た光の波長域が限られていて，波長に対する依存性が十分利用できなかった点にある。金星については 観測資料が少いので円偏光の表面分布についての理論的予湘図を作製した。

以上のように, 惑星大気に対する直接の応用では明白な結論がえられていないが, てれは主に観測資 料が不十分なためであって, 将来, 紫外から赤外に至る広域同時観测などによって申請者の理論的予測 が実証されていくものと期待される。ての意味に抢いて本論文は惑星大気中での散乱過程に関する基礎 的な理論的研究であるに止まらず, 今後の観測に対する興味深い問題提起をふくむむのとして高く評価 できる。

参考諭文 6 篇はいずれも輻射輪達ならびに光の散乱過程に関する理論的研究であって, 天体物理学拈 よび惑星大気物理学の分野に扣いて申請者が高い学識と研究能力をもっているととを示すものである。 よって，本論文は理学博士の学位論文として洒值あるものと認める。 